\title{
Combined effects of photoperiod and temperature on growth and survival of African catfish (Clarias gariepinus, Burchell 1822) larvae under laboratory conditions
}

Paul Sagwe Orina, Joseph Rasowo, Elijah Oyoo-Okoth, Safina Musa, Jonathan M. Munguti \& Harrison Charo-Karisa

To cite this article: Paul Sagwe Orina, Joseph Rasowo, Elijah Oyoo-Okoth, Safina Musa, Jonathan M. Munguti \& Harrison Charo-Karisa (2016) Combined effects of photoperiod and temperature on growth and survival of African catfish (Clarias gariepinus, Burchell 1822) larvae under laboratory conditions, Journal of Applied Aquaculture, 28:1, 17-25, DOI: 10.1080/10454438.2015.1113763

To link to this article: https://doi.org/10.1080/10454438.2015.1113763

曲 Published online: 22 Apr 2016.

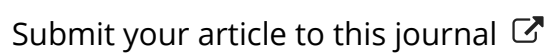

Llll Article views: 79

View Crossmark data ¿ 


\title{
Combined effects of photoperiod and temperature on growth and survival of African catfish (Clarias gariepinus, Burchell 1822) larvae under laboratory conditions
}

\author{
Paul Sagwe Orina ${ }^{a}$, Joseph Rasowo ${ }^{b}$, Elijah Oyoo-Okoth ${ }^{c}$, Safina Musad, \\ Jonathan M. Mungutie, and Harrison Charo-Karisa ${ }^{f}$ \\ aDepartment of Biological Sciences, University of Eldoret, Eldoret, Kenya; ${ }^{b}$ Department of Biological \\ and Physical Sciences, Moi University, Eldoret, Kenya; 'School of Natural Resources and Environmental \\ Studies, Karatina University, Karatina, Kenya; 'Kenya Marine and Fisheries Research Institute, Kegati \\ Aquaculture Research Station, Kisii, Kenya; ${ }^{\circ}$ Kenya Marine and Fisheries Research Institute, Sagana \\ Aquaculture Research Center, Sagana, Kenya; fState Department of Fisheries, Nairobi, Kenya
}

\begin{abstract}
The effect of photoperiod (24L:00D, 12L:12D, and 00L:24D) and temperature $\left(22 \pm 1^{\circ} \mathrm{C}\right.$ and $\left.28 \pm 1^{\circ} \mathrm{C}\right)$ on performance of Clarias gariepinus larvae was tested. Larvae weighing $3.2 \pm 0.24 \mathrm{mg}$ were cultured in aquaria at a stocking density of 20 fish $\mathrm{L}^{-1}$ and fed twice a day on catfish starter diet $(40 \% \mathrm{CP})$ at $10 \% \mathrm{BW}$ day $^{-1}$. Highest mean weight gain $(31.00 \mathrm{mg})$, SGR $(7.56 \%$ day $\left.^{-1}\right)$, and survival $(83 \%)$ were achieved at photoperiod and temperature combination of $00 \mathrm{~L}: 24 \mathrm{D}$ and $28 \pm 1{ }^{\circ} \mathrm{C}$. Percent survival of larvae differed significantly $(p<.05)$ among treatments with optimal survival of ( $83 \%)$ in treatment combination of $28 \pm 1^{\circ} \mathrm{C}$ and $00 \mathrm{~L}: 24 \mathrm{D}$, while lowest survival (40\%) in treatment combination of $22 \pm 1^{\circ} \mathrm{C}$ and $24 \mathrm{~L}: 00 \mathrm{D}$.
\end{abstract}

\section{KEYWORDS}

Clarias gariepinus; growth; photoperiod; survival; temperature

\section{Introduction}

The main constraint facing the culture of C. gariepinus is low and highly variable survival of larval stages, especially during fluctuating weather conditions (De Graaf and Janssen 1996). Growth optimization is of paramount importance for profitability of fish farming activity. Within a given species, numerous factors can influence fish growth, among which the most important is probably temperature (Gardeur et al. 2007). Temperature regulates metabolic activity, and all fish species are characterized by a range of temperature within which growth is maximal (Jobling 1996; Person-Le Ruyet et al. 2006; Bjornsson et al. 2007). Previous studies indicate a temperature range of $25^{\circ} \mathrm{C}-33^{\circ} \mathrm{C}$ with $28^{\circ} \mathrm{C}$ being the best for $\mathrm{C}$. gariepinus. Verreth and Den Bieman (1987) recommended $28 \pm 1^{\circ} \mathrm{C}$ as the optimal rearing range for $C$. gariepinus larvae. However, one factor alone may not necessarily have an effect on performance without interactions with other factors.

CONTACT Paul Sagwe Orina paulorina@gmail.com, porina@kmfri.co.ke @ Department of Biological Sciences, University of Eldoret, P.O. Box 1125-30100, Eldoret, Kenya.

Color versions of one or more of the figures in the article can be found online at www.tandfonline.com/wjaa. 
Photoperiod is known to have an effect on the feeding activity, growth, and survival of fish, thus influencing overall performance (Nwosu and Holzlöhner 2000; Adewolu et al. 2008). Ogbe et al. (2001) reported C. gariepinus as bottom feeders feeding comfortably in the dark. The effect of photoperiod on growth and survival of C. gariepinus at the larval stage has been demonstrated by several authors (Britz and Pienaar 1992; Appelbaum and Kamler 2000; Appelbaum and McGeer 1998a; Almazán-Rueda et al. 2004). To date, the combined effect of photoperiod and temperature on $C$. gariepinus larval development is yet to be reported.

\section{Materials and methods}

Experimental fish were obtained from the hatchery at Chepkoilel University College fish farm in Eldoret, Kenya. To determine mean initial wet body weight (BW) and mean total length (L), 30 three-day-old C. gariepinus larvae were collected from a pool of hatchlings. They were measured for wet BW on a Sartorius analytical electronic balance (readability $0.001 \mathrm{mg}$, Model VI200) and total length using a hand transparent plastic ruler to the nearest $0.1 \mathrm{~mm}$. A total of 18 aquaria with a 20L capacity were each stocked with 200 catfish larvae (mean BW $3.20 \pm 0.24 \mathrm{mg}$ ) in $10 \mathrm{~L}$ water at a stocking rate of 20 larvae $\mathrm{L}^{-1}$.

The larvae were randomly distributed in 18 glass aquaria in triplicates of three photoperiods and two rearing temperatures in a $3 \times 2$ (photoperiod $\times$ temperature) factorial nested design. The three photoperiods, $24 \mathrm{~h}$ of light (24L:00D), $12 \mathrm{~h}$ of light and $12 \mathrm{~h}$ of darkness (12L:12D), and $24 \mathrm{~h}$ of darkness (0L:24D) in combination with two temperatures $\left(22 \pm 1^{\circ} \mathrm{C}\right.$ and $\left.28 \pm 1^{\circ} \mathrm{C}\right)$ were randomly assigned to the 18 tanks. Two fluorescent tube lights of $40 \mathrm{~W}$ (Philips ${ }^{\circledast}$ TLD 36/54, Netherlands) providing 100 lux of light were used to give the required $24 \mathrm{~h}$ of continuous light for $24 \mathrm{~L}: 00 \mathrm{D}$. To provide $24 \mathrm{~h}$ of darkness (00L:24D), a black cellophane polythene paper was used to cover the rearing units throughout the experiment. For the $12 \mathrm{~L}: 12 \mathrm{D}$, the fluorescent light was available except that the rearing units were covered for half the time with the polythene paper. Temperatures of $22 \pm 1^{\circ} \mathrm{C}$ and $28 \pm 1^{\circ} \mathrm{C}$ were maintained with submersible aquarium water heaters.

Larvae were fed a commercial catfish starter feed at $10 \%$ of the larvae's body weight and administered in two equal portions daily at $0800 \mathrm{~h}$ and $1600 \mathrm{~h}$. Nutrient composition of the commercial starter feed is shown in Table 1. The experiment lasted for 4 weeks after stocking. Water quality in the tanks was maintained by siphoning out the bottom debris (fecal matter, uneaten food) and replacing $1 / 3$ of the water every morning $(0700 \mathrm{~h})$ before feeding. Water for replacement was obtained from two (500L) temperatureregulated storage tanks. Temperature and $\mathrm{pH}$ were recorded daily at $0600 \mathrm{~h}$ using a mercury thermometer and a $\mathrm{pH}$ meter, respectively. Dissolved 
Table 1. Nutrient content of the commercial catfish starter feed.

\begin{tabular}{ll}
\hline Nutrient & Quantity \\
\hline Protein & $40 \%$ \\
Fat & $10 \%$ \\
Ash & $9 \%$ \\
Fiber & $1.1 \%$ \\
Calcium & $2.4 \%$ \\
Phosphorus & $1.5 \%$ \\
Lysine & $3.2 \%$ \\
Methionine + Cystine & $2 \%$ \\
Copper & $10 \mathrm{mg} \mathrm{kg}^{-1}$ \\
Vitamin A & $30,000 \mathrm{IU} \mathrm{kg}^{-1}$ \\
Vitamin D3 & $3000 \mathrm{IU} \mathrm{kg}^{-1}$ \\
Vitamin E & $400 \mathrm{IU} \mathrm{kg}^{-1}$ \\
Vitamin C & $300 \mathrm{~g} \mathrm{~kg}^{-1}$ \\
Selenium & $0.4 \mathrm{~m} \mathrm{~g} \mathrm{~kg}^{-1}$ \\
\hline
\end{tabular}

oxygen, total ammonia nitrogen $\left(\mathrm{NH}_{3}-\mathrm{N}\right)$, and nitrite-nitrogen $\left(\mathrm{NO}_{2}-\mathrm{N}\right)$ were measured at intervals of 14 days using the indophenol and colored azo methods respectively (Boyd and Tucker 1992).

Growth was measured weekly for a period of 4 weeks. Each time, 30 larvae were randomly sampled from each tank and measured for growth (total length and wet body weight). Mortalities were recorded before every feeding $(0800$ and $1600 \mathrm{~h})$. Mean weight per tank was used to adjust weekly food rations. Specific growth rate (SGR), \% weight gain, relative condition factor, and percent survival of the larvae was calculated with the following formulae:

$$
\text { Specific growth rate SGR }=100\left(\ln \mathrm{W}_{\mathrm{t}}-\ln \mathrm{W}_{0} / \mathrm{t}\right)
$$

where: $-\left(\ln =\right.$ Natural logarithm, $\mathrm{W}_{0}=$ Initial weight $(\mathrm{g}), \mathrm{Wt}=$ Final weight $(\mathrm{g})$, and $\mathrm{t}=$ Time (days).

$$
\begin{aligned}
\text { Weight gain }(\%)= & (\text { Final weight of fish }- \text { Initial weight of fish }) \\
& \times 100 / \text { Initial weight of fish } .
\end{aligned}
$$

$$
\text { Relative condition factor }=\mathrm{W} / \hat{\mathrm{W}}
$$

(where $\mathrm{W}=$ observed weight of the fish, $\hat{\mathrm{W}}$ = predicted weight of the fish from length - weight relationship $(\log W=\log a+b \log L)$.

Percent survival $\%=$ Initial number of larvae in the tank

- Number of dead larvae

$$
\times 100 / \text { Initial number of larvae in the tank. }
$$

The combined effect of photoperiod and temperature on survival was determined after counting the remaining fish in the tank at the end of the experiment. Data were tested for normality using Shapiro-Wilk's W test and analyzed using MINITAB version 13. Statistical comparison of 
data among treatments for mean growth and survival were made with two-way analysis of variance (ANOVA) at $p=.05$. Duncan's multiple range test was used to identify specific differences among treatments. Correlation analysis was conducted to establish relationship between treatments (photoperiod, temperature) and growth and survival of catfish larvae.

\section{Results}

Growth responses for C. gariepinus under the different treatments are shown in Table 2. Final mean BW, L, and SGR ranges were 11.52-1.00 mg, 12.91$17.46 \mathrm{~mm}, 4.57-7.56 \%$ day $^{-1}$, respectively. Final mean wet body weight, total length, and specific growth rates differed among treatments. Significant interactions $(p<.05)$ between temperature and photoperiod were evident in growth performance parameters mean BW, length gain, and SGR. Mean (and percentage) weight and length gains as well as SGR of C. gariepinus were significantly higher at a combined treatment of $28 \pm 1{ }^{\circ} \mathrm{C}$ and 00L:24D (total darkness) temperature and photoperiod, respectively, than the other treatments. Mean growth in weight and SGR in C. gariepinus larvae at $22 \pm 1^{\circ} \mathrm{C}$ and $00 \mathrm{~L}: 24 \mathrm{D}$ did not significantly differ from that at $28 \pm 1{ }^{\circ} \mathrm{C}$ and 12L:12D. Poorest SGR (4.57 \pm 0.92$)$, mean weight gain $(8.31 \pm 1.74 \mathrm{mg})$, and mean gain in length $(5.63 \pm 0.42 \mathrm{~mm})$ were obtained at $22 \pm 1^{\circ} \mathrm{C}$ and 24L:00D temperature and photoperiod regimes respectively. Generally, at each of the temperatures tested $\left(22 \pm 1^{\circ} \mathrm{C}\right.$ and $\left.28 \pm 1^{\circ} \mathrm{C}\right)$, total darkness gave the best growth performance (Table 2).

C. gariepinus larvae growth curves are shown in Figures 1 and 2 for length and weight gain respectively. Both temperature and photoperiod significantly $(p<.05)$ affected fish growth. Compared to other treatments, growth in total darkness (00L:24D) was significantly faster $(p<.05)$. Continuous light $(24 \mathrm{~L}$ : 00D) produced significantly $(p<.05)$ slower growth throughout the experiment.

Figure 3 indicates that survival response of C. gariepinus larvae was significantly affected by interaction between temperature and photoperiod $(p<.05)$. Regardless of the photoperiod, $28 \pm 1^{\circ} \mathrm{C}$ resulted in significantly higher survival than $22 \pm 1^{\circ} \mathrm{C}$ (Figure 3). Survival of C. gariepinus larvae was highest (83\%) in aquaria combination of $28 \pm 1^{\circ} \mathrm{C}$ and total darkness. The lowest survival (40\%) occurred at $22 \pm 1^{\circ} \mathrm{C}$ and continuous light (24L:00D). Unlike fish in half (12L:12D) and continuous darkness (00L:24D), larvae in continuous light tended to congregate in aquaria corners, seemingly nervous and/or in search of dark areas.

Water total ammonia (TA), $\mathrm{pH}$, total ammonia nitrogen (TAN), dissolved oxygen (DO), and nitrite $\left(\mathrm{NO}_{2}-\mathrm{N}\right)$ were within the acceptable levels for growth of C. gariepinus. All measured parameters except DO presented no 


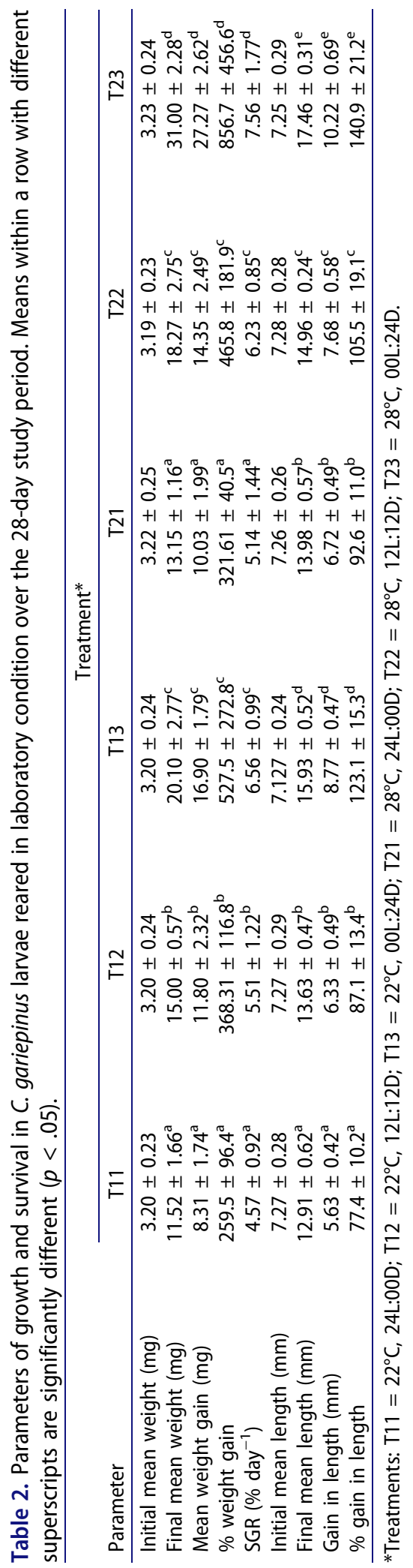




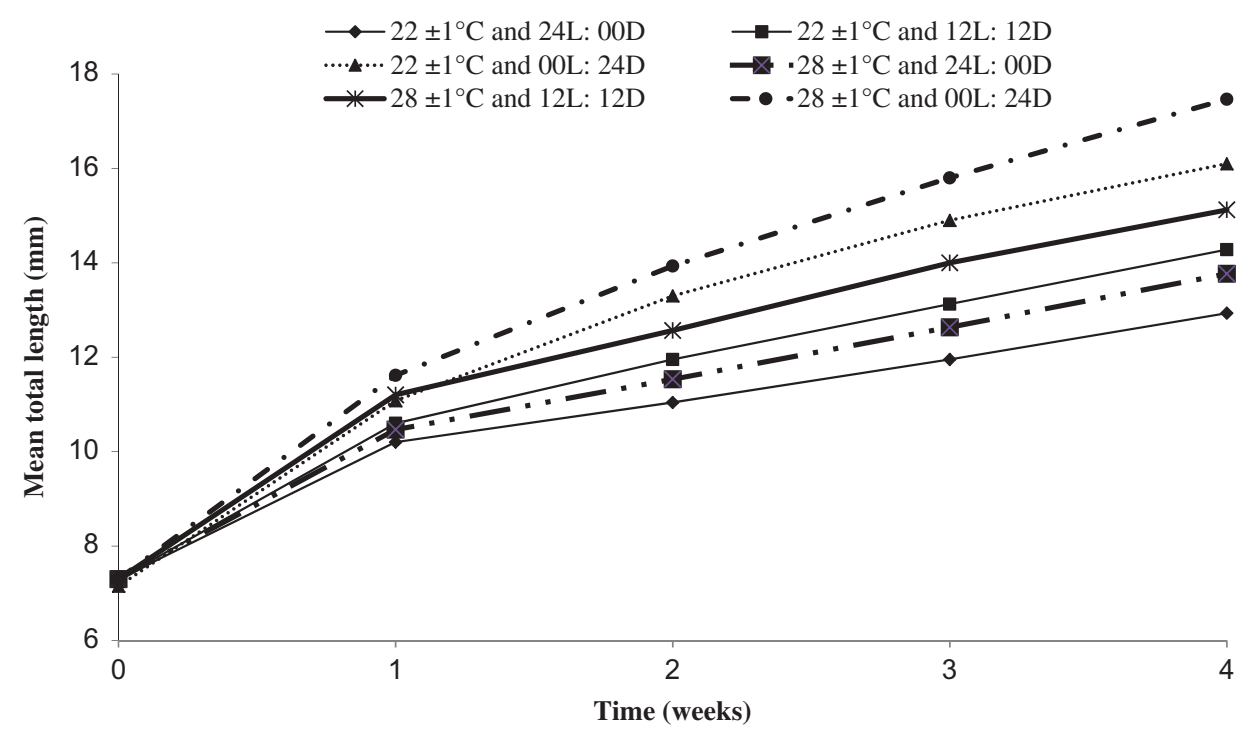

Figure 1. Mean total length $( \pm S E)$ of $C$. gariepinus larvae under different photoperiod and temperature combinations during a 4-week experiment period.

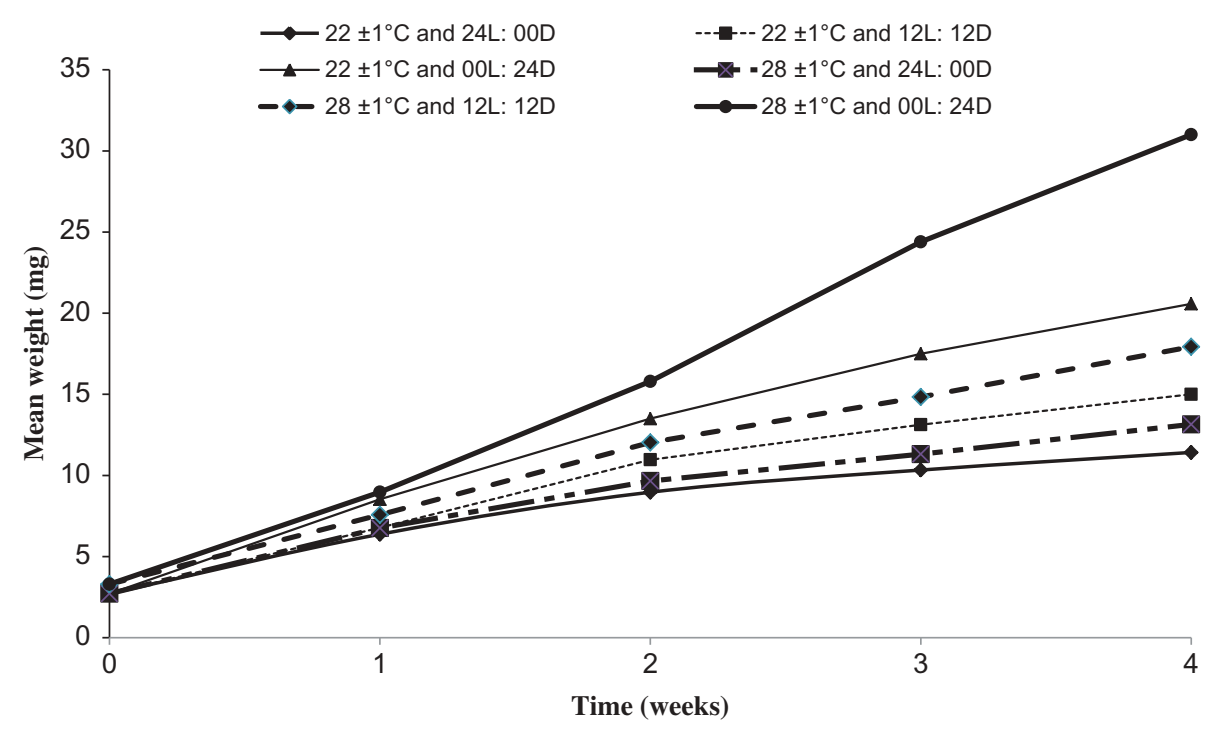

Figure 2. Mean wet weight $( \pm \mathrm{SE})$ of $C$. gariepinus larvae under different photoperiod and temperature combinations over a 4-week experiment period.

significant differences $(p>.05)$ within and among treatments (Table 3). Aquaria at $28 \pm 1^{\circ} \mathrm{C}$ had a significantly $(p<.05)$ lower DO than aquaria at $22 \pm 1^{\circ} \mathrm{C}$. Nevertheless, an interaction between photoperiod and temperature did not have any significant effect $(p>.05)$ on TA, pH, TAN, DO, and $\mathrm{NO}_{2}-\mathrm{N}$ among treatments. 


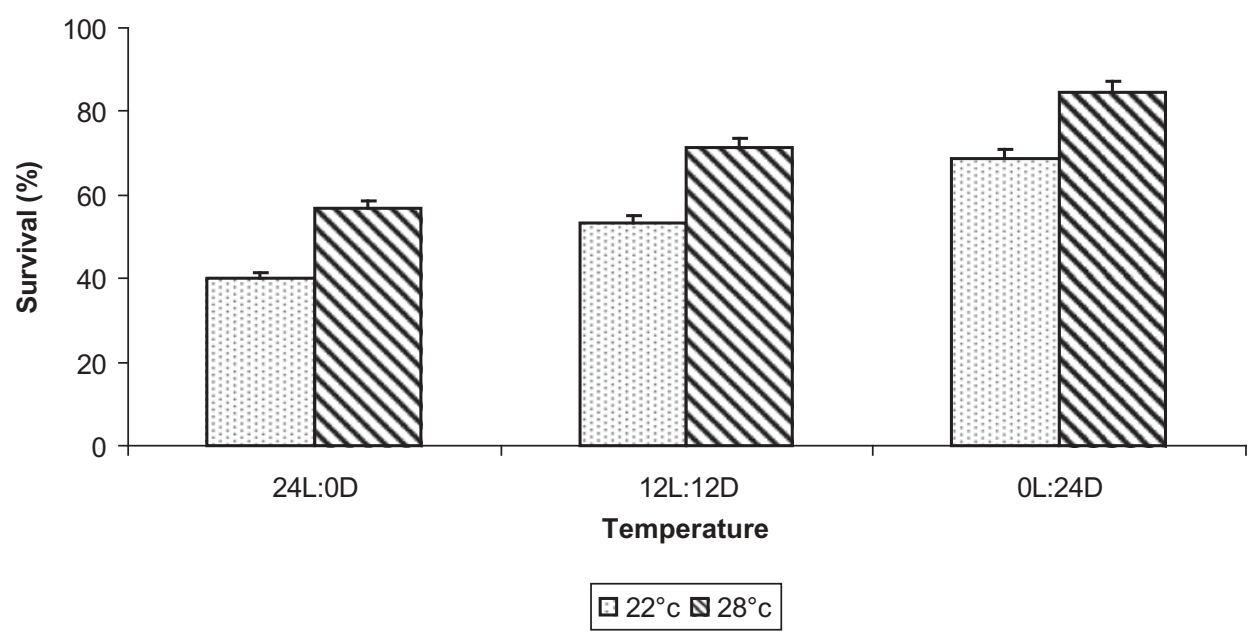

Figure 3. Mean survival trend of $C$. gariepinus larvae under different photoperiod and temperature combinations during a 4-week experiment period.

Table 3. Mean $( \pm \mathrm{SE})$ water quality parameters in various treatments under laboratory condition over 28-day period. Means within a row lacking a common superscript are significantly different $(p<.05)$. SE = standard error, calculated from the mean-square for error of the ANOVA, $\mathrm{TA}=$ total alkalinity, TAN $=$ total ammonia nitrogen, and $\mathrm{DO}=$ dissolved oxygen.

\begin{tabular}{lcccccc}
\hline & \multicolumn{5}{c}{ Treatment } \\
\cline { 2 - 7 } Variable & T11 & T12 & T13 & T21 & T22 & T23 \\
\hline TA $\left(\mathrm{mg} \mathrm{CaCO}_{3} \mathrm{I}^{-1}\right)$ & $108.1 \pm 3.4^{\mathrm{a}}$ & $100.5 \pm 6.9^{\mathrm{a}}$ & $102.2 \pm 8.4^{\mathrm{a}}$ & $73.9 \pm 7.9^{\mathrm{a}}$ & $73.9 \pm 7.9^{\mathrm{a}}$ & $73.9 \pm 7.9^{\mathrm{a}}$ \\
$\mathrm{pH}$ & $7.5 \pm 0.8^{\mathrm{a}}$ & $7.1 \pm 0.7^{\mathrm{a}}$ & $7.2 \pm 0.7^{\mathrm{a}}$ & $7.0 \pm 0.7^{\mathrm{a}}$ & $7.6 \pm 0.8^{\mathrm{a}}$ & $6.9 \pm 0.7^{\mathrm{a}}$ \\
$\mathrm{TAN}\left(\mathrm{mgl}^{-1}\right)$ & $0.6 \pm 0.1^{\mathrm{a}}$ & $0.6 \pm 0.1^{\mathrm{a}}$ & $0.5 \pm 0.1^{\mathrm{a}}$ & $0.6 \pm 0.1^{\mathrm{a}}$ & $0.6 \pm 0.1^{\mathrm{a}}$ & $0.6 \pm 0.1^{\mathrm{a}}$ \\
Dawn DO $\left(\mathrm{mgl}^{-1}\right)$ & $4.2 \pm 1.4^{\mathrm{b}}$ & $4.2 \pm 1.4^{\mathrm{b}}$ & $4.2 \pm 1.4^{\mathrm{b}}$ & $3.0 \pm 0.3^{\mathrm{a}}$ & $3.1 \pm 0.5^{\mathrm{a}}$ & $3.0 \pm 1.4^{\mathrm{b}}$ \\
$\mathrm{NO}_{2}-\mathrm{N}\left(\mathrm{mgl}^{-1}\right)$ & $<0.03^{\mathrm{a}}$ & $<0.03^{\mathrm{a}}$ & $<0.02^{\mathrm{a}}$ & $<0.02^{\mathrm{a}}$ & $<0.02^{\mathrm{a}}$ & $<0.02^{\mathrm{a}}$ \\
\hline
\end{tabular}

${ }^{*}$ Treatments: $\mathrm{T} 11=22^{\circ} \mathrm{C}, 24 \mathrm{~L}: 00 \mathrm{D} ; \mathrm{T} 12=22^{\circ} \mathrm{C}, 12 \mathrm{~L}: 12 \mathrm{D} ; \mathrm{T} 13=22^{\circ} \mathrm{C}, 00 \mathrm{~L}: 24 \mathrm{D} ; \mathrm{T} 21=28^{\circ} \mathrm{C}, 24 \mathrm{~L}: 00 \mathrm{D}$; $\mathrm{T} 22=28^{\circ} \mathrm{C}, 12 \mathrm{~L}: 12 \mathrm{D} ; \mathrm{T} 23=28^{\circ} \mathrm{C}, 00 \mathrm{~L}: 24 \mathrm{D}$.

\section{Discussion}

These results corroborate previous findings that C. gariepinus larvae are photophobic and eat more effectively in darkness (Hogendoorm 1980; Britz and Pienaar 1992; Bruton 1979a, 1979b; Appelbaum and McGeer 1998b). Behavioral studies have illustrated that avoidance of light and preference for dark areas is an innate behavior in young C. gariepinus (Britz and Pienaar 1992).

Rather than increased light, making it easier for the C. gariepinus larvae to spot the feed, the larvae were probably stressed by the presence of light and could therefore not feed comfortably (Adewolu et al. 2008). Under continuous light, there are higher chances of developing aggressive behavior, thus limiting feed intake. This is in line with Britz and Pienaar (1992), Appelbaum and Kamler (2000), and Verreth and Van Tongeren (1989), who observed that swimming and aggressive behavior of C. gariepinus larvae increased with 
prolonged exposure to light. This eventually results in poor growth, which is attributed to less resting time for the fish. Lower weight gains may be attributed to the fish being more stressed and aggressive under continuous light conditions, compared to those under 12D:12L and 24D:00L. This corroborates earlier studies on photoperiod and temperature (AlmazánRueda et al. 2004; Almazán-Rueda et al. 2005).

Study findings indicate low-light regimens and low temperatures lead to reduced rates of cannibalism, low activity, and high feeding rates of African catfish larvae. The higher survival found in fish cultured in the dark regardless of the temperature are in agreement with previous findings (Appelbaum and McGeer 1998a; Appelbaum and Kamler 2000; Adewolu et al. 2008) that demonstrated that larval behavior ensures growth in an environment most conducive for survival. Further studies indicate that photoperiod and temperature are among factors that regulate such behavior (Coward and Bromage 2000; Bromage et al. 2001). In nature, the African catfish is known to spawn in flooded streams, and fertilized eggs attach to reeds and grasses, providing darker conditions. Thus the combined effect of reduced photoperiod and increased temperature appears to be nature's way of ensuring greater survival and growth of C. gariepinus larvae.

\section{References}

Adewolu, M. A., C. A. Adeniji, and B. Adejobi. 2008. Feed utilization, growth and survival of Clarias gariepinus (Burchell 1822) fingerlings cultured under different photoperiods. Aquaculture 283:64-67. doi:10.1016/j.aquaculture.2008.07.020.

Almazán-Rueda, P., J. W. Schrama, and J. A. J. Verreth. 2004. Behavioural responses under different feeding methods and light regimes of the African catfish (Clarias gariepinus) juveniles. Aquaculture 231:347-359. doi:10.1016/j.aquaculture.2003.11.016.

Almazán-Rueda, P., A. T. M. Van Helmond, J. A. J. Verreth, and J. W. Schrama. 2005. Photoperiod affects growth, behaviour and stress variables in Clarias gariepinus. Journal of Fish Biology 67:1029-1039. doi:10.1111/j.0022-1112.2005.00806.x.

Appelbaum, S., and E. Kamler. 2000. Survival, growth, metabolism and behaviour of Clarias gariepinus (Burchell 1822) early stages under different light conditions. Aquacultural Engineering 22:269-287. doi:10.1016/S0144-8609(00)00054-6.

Appelbaum, S., and J. C. McGeer. 1998a. Effect of diet and light regime on growth and survival of African catfish (Clarias gariepinus) larvae and early juveniles. Aquaculture Nutrition 4(3): 157-164. doi:10.1046/j.1365-2095.1998.00064.x.

Appelbaum, S., and J. C. McGeer. 1998b. Effect of diet and light regime on growth and reproduction of African catfish. Journal of the World Aquaculture Society 24:246-261.

Bjornsson, B., A. Steinarsson, and T. Árnason. 2007. Growth model for Atlantic cod (Gadus morhua): Effects of temperature and body weight on growth rate. Aquaculture 271:216226. doi:10.1016/j.aquaculture.2007.06.026.

Boyd, C. E., and C. S. Tucker. 1992. Water quality and pond soil analyses for aquaculture, 183. Auburn University, AL: Alabama Agricultural Experiment Station, Auburn University. 
Britz, P. J., and A. G. Pienaar. 1992. Laboratory experiments on the effect of light and cover on the behaviour and growth of African catfish, Clarias gariepinus (Pisces: Clariidae). Journal of Zoology London 227:43-62. doi:10.1111/jzo.1992.227.issue-1.

Bromage, N., M. Porter, and C. Randall. 2001. The environmental regulation of maturation in farmed finfish with special reference to the role of photoperiod and melatonin. Aquaculture 197:63-98. doi:10.1016/S0044-8486(01)00583-X.

Bruton, M. N 1979a. The breeding biology and early development of Clarias gariepinus (Pisces: Clariidae) in Lake Sibaya, South Africa, with a review of breeding species of the subgenus Clarias (Clarias). Transactions Zoological Social London 35:1-45. doi:10.1111/ j.1096-3642.1979.tb00056.x.

Bruton, M. N. 1979b. The food and feeding behaviour of Clarias gariepinus (Pisces: Clariidae) in Lake Sibaya, South Africa, with its emphasis on its role as a predator of cichlids. Transactions Zoological Social London 35:47-114. doi:10.1111/j.1096-3642.1979.tb00057.x.

Coward, K., and N. R. Bromage. 2000. Reproductive physiology of female tilapia broodstock. Reviews in Fish Biology and Fisheries 10:1-25. doi:10.1023/A:1008942318272.

De Graaf, G. J., and H. Janssen. 1996. Artificial reproduction and pond rearing of the African catfish, Clarias gariepinus, in sub-Saharan Africa: A handbook. FAO Fisheries Technical Paper. No. 362. Rome: FAO, 73.

Gardeur, J.-N., N. Mathis, A. Kobilinsky, and J. Brun-Bellut. 2007. Simultaneous effects of nutritional and environmental factors on growth and flesh quality of Perca fluviatilis using a fractional factorial design study. Aquaculture 273:50-63. doi:10.1016/j.aquaculture. 2007.09.024.

Hogendoorm, H. 1980. Controlled propagation of African catfish, Clarias lazera (C. and V.) III. Feeding and growth of fry. Aquaculture 21:233-241.

Jobling, M. 1996. Temperature and growth: Modulation of growth rate via temperature change. In Global warming: Implications for freshwater and marine fish, ed. C. M. Wood and D. G. McDonald, 225-253. Cambridge, UK: Cambridge University Press.

Nwosu, F. M., and S. Holzlöhner. 2000. Effect of stocking density on growth, survival of Heterobranchus longifilis Val. 1840 Co (Teleostei: Clariidae) larvae after 14 days of rearing. Journal of Applied Ichthyology 16:24-26. doi:10.1046/j.1439-0426.2000.00145.x.

Ogbe, F. G., P. A. Annune, and O. A. Soremi. 2001. Aquaculture development in Benue State: Technology and socio-economic states. Journal of Research and Review in Science 2:289-291.

Person-Le Ruyet, J., V. Buchet, B. Vincent, H. Le Delliou, and L. Quéméner. 2006. Effects of temperature on the growth of pollack (Pollachius pollachius) juveniles. Aquaculture 251:340-345. doi:10.1016/j.aquaculture.2005.06.029.

Verreth, J., and H. Den Bieman. 1987. Quantitative feed requirements of African catfish Clarias gariepinus larvae fed with decapsulated cysts of Artemia. 1. The effect of temperature and feeding level. Aquaculture 63:251-267. doi:10.1016/0044-8486(87)90077-9.

Verreth, J., and M. van Tongeren. 1989. Weaning time in Clarias gariepinus (Burchell) larvae. Aquaculture 83:81-88. doi:10.1016/0044-8486(89)90062-8. 